\title{
Samarbejde via social kapital og relationel koordinering - hvem trækker det læengste strå?
}

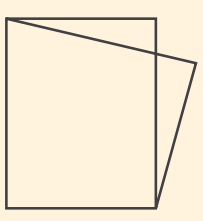

Vibeke Andersen, lektor, Institut for Læring og Filosofi, Aalborg Universitet; Anette Lykke Hindhede, lektor, ph.d., Institut for Læring og Filosofi, Aalborg Universitet \& Jette Ernst, videnskabelig assistent, ph.d., Institut for Sprog og Kommunikation, Syddansk Universitet
Artiklen har fokus på, hvordan et sociologisk begreb som social kapital transformeres til et organisatorisk begreb og indarbejdes i ledelseskoncepter, hvor begrebet får en ganske anden betydning. Artiklen forholder sig kritisk til to ledelseskoncepter: Virksomhedens sociale kapital og relationel koordinering og viser gennem en undersogelse indenfor hospitalssektoren, hvordan koncepterne er med til at legitimere en ledelsespraksis og magtforhold, der ligger langt fra begrebernes oprindelige betydning. Det fremgår tillige, at der er store udfordringer med at leve op til det, koncepterne lover, nemlig at skabe overensstemmelse mellem produktivitet, kvalitet og et godt psykisk arbejdsmiljø.

\section{Introduktion til artiklen}

Som det er tilfældet andre steder i verden, gennemgår den danske hospi- talssektor gennemgribende reformer disse år. Udfordringerne er store med en befolkning, der forventes at leve længere og dermed har et voksende behandlingsbehov, stigninger i en række kroniske sygdomme og voksende udgifter til behandlinger, samtidig med at de offentlige udgifter skal begrænses. Således har hospitalerne i en årrække været underlagt et krav om en produktivitetsstigning på 2 \% pr. år; et krav som fortsat håndhæves. New Public Management inspirerede styringsteknologier har vundet indpas gennem 1990'erne og OO'erne med et øget fokus på produktivitet og kvalitet. Lean ledelse er blevet indført med det formål at strømline og slanke arbejdsgangene på hospitalerne for herved at øge produktiviteten, men der skal mere til.

Historisk har det vist sig at være vanskeligt at gennemføre forandringer 
i hospitalssektoren, hvilket bl.a. begrundes med et udstrakt selvstyre, som de professionelle faggrupper har oparbejdet, og som har muliggjort en vis modstand mod forandringstiltag (Vinge 2004). Det synes derfor oplagt at fokusere på medarbejderne og på samarbejdet mellem faggrupperne som løsningen på sektorens mangfoldige udfordringer. Social kapital og relationel koordinering adresserer da også begge den opfattelse, at løsningen på sektorens problemer skal findes blandt de ansatte ved at øge koordinationen og samarbejdet mellem faggrupperne (Hagedorn-Rasmussen 2014). Argumentet er, at det vil være til fordel for økonomien, kvaliteten, patienttilfredsheden samt medarbejdernes trivsel og psykiske arbejdsmiljø. Men som vi viser $\mathrm{i}$ artiklen, er der en del problemer forbundet hermed. Vor interesse i denne artikel er kritisk at diskutere, hvordan ledelseskoncepter med fokus på social kapital og samarbejde er med til at legitimere en ledelsespraksis og magtforhold, der ligger langt fra de sociologiske begreber, hvorfra de henter deres inspiration, og hvilke udfordringer ledelseskoncepterne har med at leve op til det, de lover, nemlig at skabe overensstemmelse mellem produktivitet, kvalitet og et godt psykisk arbejdsmiljø.

$\mathrm{Vi}$ indleder artiklen med at introducere et sociologisk begreb om social kapital og viser, hvordan begrebet transformeres til organisatoriske begreber $\mathrm{i}$ to ledelseskoncepter: virksomhedens sociale kapital og relationel koordinering. Herefter viser vi med udgangspunkt i et forskningsprojekt indenfor hospitalssektoren, hvordan de organisatoriske koncepter implementeres og opleves af medarbejderne, hvorefter vi afslutter artiklen med at diskutere, hvilke udfordringer det skaber, når fokus flyttes fra løsning af de daglige arbejdsopgaver til at måle på social kapital. Vi stiller spørgsmålet, hvem der trækker det længste strå, når social kapital og relationel koordinering indføres i hospitalssektoren.

\section{Sociologiske koncepter på vandring} Sociologen Portes (1998) gjorde allerede for 20 år siden opmærksom på, at social kapital, i lighed med mange andre sociologiske koncepter, havde ændret sig fra dets oprindelige betydning til et praktisk værktøj, der blev præsenteret, som om det kunne kurere allehånde problemer. Vi ser en tilsvarende bevægelse i dag, hvor social kapital er blevet transformeret til organisatorisk social kapital og dermed til et ledelseskoncept. At sociologiske koncepter vandrer og skifter betydning er ikke usædvanligt, alligevel er der grund til at være opmærksom på den betydning, det har, når et ledelseskoncept refererer direkte til sociologiske teorier, idet det skaber en særlig autoritet og positiv forventning hos modtagerne. Det gør begrebet universelt og dermed vanskeligt at opponere imod. Koncepterne virksomhedens sociale kapital og relationel koordinering, som vi i denne artikel diskuterer i forbindelse med deres indtog i hospitalssektoren, henter begge deres teoretiske legitimation i sociologisk teori.

Vi finder det vigtigt at vise den rejse, som de teoretiske begreber gennemløber, da referencen til de teoretiske begreber er med til at fjerne opmærksomheden fra, at de først og fremmest er organisatoriske ledelseskoncepter. Det fokus, der er på at forbedre samarbejdet i almindelighed og det tværprofessionelle samarbejde i særdeleshed, har derfor som sit primære formål at øge produktiviteten og effektiviteten.
Begrebet social kapital har sin oprindelse flere steder og bygger på forskellige forståelser og videnskabsteoretiske paradigmer. Her vil vi alene nævne Bourdieu og Putnam, som udgør de primære sociologiske inspirationer for koncepterne virksomhedens sociale kapital og relationel koordinering. Hos Pierre Bourdieu (1986) er kapitalbegrebet et meget centralt begreb, som han bruger til at begrebsliggøre de ressourcer og egenskaber, som individer er i besiddelse af, og som de drager nytte af i det sociale rum. Kapital optræder hos Bourdieu i tre hovedformer: økonomisk, kulturel og social, hvor kun den økonomiske er af ren materiel karakter. For at noget kan få karakter af kapital, må det være omsætteligt, dvs. der må være et marked eller en afsætningsmulighed indenfor et bestemt felt. Bourdieu forstår social kapital som en ressource relateret til gruppemedlemskab og sociale netværk. Han interesserer sig for selve den sociale relation, der gør det muligt for individet at skaffe sig adgang til de ressourcer, som besiddes af andre individer i den pågældende relation og for kvaliteten af ressourcerne i relationen.

Robert Putnam (1995) har en anden forståelse af social kapital end Bourdieu, idet han baserer sit begreb om social kapital på et kvantitativt og statistisk orienteret grundlag, som han anvender til at kortlægge samfundstendenser på makroniveau. Hans interesse er at måle og dokumentere reduktionen $\mathrm{i}$ social kapital i en amerikansk kontekst. Ifølge Putnam består social kapital af tre elementer: normer, tillid og netværk, idet han forstår social kapital som det kit, der binder samfundet sammen i form af tillid og udvikling af fælles normer og forpligtelser. Han har fokus på samfun- 


\section{Social kapital er blevet transformeret til organisatorisk social kapital og dermed til et ledelseskoncept.}

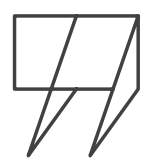

dets sammenhængskraft, som afspejler sig i, at folk agerer uegennyttigt overfor hinanden. Han betragter således social kapital som et offentligt gode, der dannes, når folk mødes, ses og taler sammen og på den måde involverer sig i hinanden.

\section{Virksomhedens sociale kapital - et dansk koncept}

I en dansk sammenhæng er det publiceringen af Hvidbogen med titlen Virksomhedens sociale kapital publiceret af Olesen, Thoft, Hasle \& Kristensen (2008), der sætter fokus på social kapital i en organisatorisk sammenhæng. Hegedahl \& Rosenmeier (2007) har året før udgivet bogen Social kapital som teori og praksis, som anlægger et handlingsorienteret sigte, men de udvikler ikke et egentligt organisatorisk værktøj, som det er tilfældet med Hvidbogen. Social kapital som organisatorisk værktøj i den danske offentlige sektor er kun sparsomt belyst i forskningslitteraturen. Det er karakteristisk for de unders $\varnothing-$ gelser, som eksisterer (f.eks. Albertsen, Wiegman \& Limborg (2014), Bruhn \& Hagedorn-Rasmussen (2013), Edwards \&
Lundstrøm (2014), Hagedorn-Rasmussen (2014), Kristensen m.fl. (2013), Limborg m.fl. (2012), Lundstrøm m.fl. (2014)), at social kapital overvejende undersøges $i$ et optimistisk lys, hvor der ikke sættes spørgsmålstegn ved konceptet. Her er Hagedorn-Rasmussen (2014) en undtagelse. Et andet karakteristikum er, at undersøgelser, som inddrager empirisk materiale, primært gør det i form af spørgeskemaundersøgelser, der søger at kortlægge sammenhænge mellem variable (f.eks. Edwards \& Lundstrøm, 2014; Limborg m.fl., 2012; Lundstrøm m.fl., 2014).

I Hvidbogen argumenteres der for, at social kapital kan være det strategiske svar på de udfordringer, der især er presserende indenfor den offentlige sektor, og hvor arbejdet med social kapital på organisatorisk plan kan have en positiv effekt på både produktivitet, kvalitet og arbejdsmiljø (Olesen m.fl. 2008: 7). Hvidbogen er forfattet af arbejdsmiljøforskere og udgivet af Det Nationale Forskningscenter for Arbejdsmiljø (NFA). Bogen skriver sig ind i den danske arbejdsmiljøforskning med et erklæret $ø$ nske om at bidrage til den danske velfærdsstats udfordringer (ibid.). Forfatterne konstruerer en teoretisk model om virksomhedens sociale kapital, som bygger på begreberne tillid, retfærdighed og samarbejde med det formål at kunne beskrive og måle en ønsket harmonisk tilstand i organisationen, som beskrives som en evne (ibid. 10), men som også bliver en norm. Inspireret af Putnams forståelse af social kapital, beskrives virksomhedens sociale kapital som det kollektive gode, som gør en given organisations medlemmer i stand til at samarbejde (ibid. 16), hvor medlemmer "koordinerer deres handlinger med henblik på at skabe fælles værdier og fordele" (ibid. 40). Det teoretiske begreb om social kapital er således transformeret til et organisatorisk begreb og ledelseskoncept med betegnelsen Virksomhedens sociale kapital, der defineres som "den egenskab, som sætter organisationens medlemmer i stand til i fællesskab at løse dens kerneopgave" med tilføjelsen "på et højt niveau af tillid og retfærdighed" (ibid. 44). 
Samarbejde via social kapital og relationel koordinering - hvem trækker det længste strå?

\section{Tillid i Social kapital}

Tillid er helt central for samarbejdsevnen i virksomhedens sociale kapital. I Tidsskrift for Professionsstudiers temanummer om tillid (nr. 22, 2016) analyseres og diskuteres tillid ud fra mange forskellige vinkler, hvor hovedparten af artiklerne alle refererer til den danske teolog og religionsfilosof Løgstrup. I Den etiske fordring definerer Løgstrup (1956/2010) tillid som noget grundlæggende for mennesket, hvor det bliver helt afgørende, om det, man har tillid til, lever op til de forventninger, man har til det. At have tillid er i denne forståelse et spørgsmål om mod, da tillid er at turde løbe en risiko. På dansk kobler vi tillid til det 'at kunne stole på', hvilket er anderledes i de nordiske sprog end på andre sprog som engelsk, tysk og fransk (Fink 2016). Det engelske begreb 'trust' og det tyske begreb 'Zutrauen' har en lidt anden betydning, som relaterer sig til ordene hård, fast og solid. Her er det risikobetonede ikke i fokus.

Tillid er i Løgstrups udlægning grundlæggende for mennesket. Tillid er der allerede. Derfor kan vi ikke love hinanden tillid, vi kan ikke beslutte os for at have tillid, vi kan ikke gøre os fortjent til tillid, men vi kan bestræbe os på ikke at gøre os fortjent til mistillid (Fink 2016: 10). Det betyder, at hvis tilliden først er brudt, kan den ikke genetableres som en bevidst beslutning, men den kan komme igen af sig selv.

I virksomhedens sociale kapital er det ikke den skandinaviske forståelse af tillid, som indgår. I stedet beskrives tillid som at "man ikke kan bestemme om en anden person har tillid til en. Det er helt op til hver enkelt person, om man vil vise tillid eller ej" (Olesen m.fl. 2008: 112-113). Det betyder, at tillid er en viljesagt, hvilket står i modsætning til Løgstrup, som siger at tillid netop ikke er noget, vi kan beslutte os til at ville. I forhold til forståelsen af virksomhedens sociale kapital er denne forskel i forståelsen af tillid helt central. Spillereglerne i virksomheder er anderledes end $\mathrm{i}$ almindelig menneskelig omgang, idet ledelsesretten allerede i udgangspunktet betyder, at nogen (ledelsen) kan påberåbe sig mere ret end andre. Når forståelsen af tillid således er noget, den enkelte kan beslutte sig for, bliver tillid noget, ledelsen kan forvente og forlange, at de ansatte udviser.

\section{Arbejdsmiljøforskning transformeres til arbejdsmiljøkonsulentarbejde}

Hvidbogens tanker bygger videre på den del af Arbejdsmiljøforskningen, som igennem årtier har arbejdet med at udvikle begreber og koncepter ud fra en konsensusopfattelse om, at god medarbejdertrivsel fremmer produktiviteten. NFA har udviklet De Seks Guldkorn som eksempler på forhold i arbejdet, der skal være til stede for at sikre et godt arbejdsmiljø (indflydelse, mening, belønning, social støtte, forudsigelighed og krav). Guldkornene er siden suppleret med De Tre Diamanter, som i dag indgår i Social kapital (tillid, retfærdighed og samarbejdsevne) (Hagedorn-

Rasmussen 2014). NFA har indarbejdet De Seks Guldkorn og Social kapital i de spørgeskemaer, som virksomheder tilbydes i forbindelse med målinger af det psykiske arbejdsmiljø. På den måde kan virksomhederne år for år måle deres sociale kapital og sammenligne sig med andre virksomheder og brancher. Det appellerende $\mathrm{i}$ at kunne måle handler om at kunne sammenligne, enten indenfor egen virksomhed, på tværs af afdelinger eller med andre virksomheder, også selvom det kan være meget uklart, hvad der måles på og hvad der sammenlignes (Edwards \& Lundstrøm 2014).

Med konceptet om virksomhedens sociale kapital indgår forskerne aktivt i transformationsprocessen fra videnskabelige begreber til konkrete ledelseskoncepter. Flere af forskerne fungerer da også som foredragsholdere på konferencer, hvor virksomhedens sociale kapital annonceres som en mulig løsning på komplekse problemer, og de indgår som konsulenter i virksomheder, som ønsker at indføre social kapital. Herved er forskerne med til at legitimere koncepterne som andet og mere end et organisatorisk koncept til at fremme produktivitet og effektivitet.

Som beskrevet i indledningen til artiklen er der et andet ledelseskoncept i omløb indenfor hospitalssektoren, der ligeledes bygger på et teoretiske begreb om social kapital, og som har vægt på koordination og samarbejde. Dette koncept betegnes relationel koordinering.

\section{Relationel koordinering - en amerikansk inspiration}

Jody Hoffer Gittell $(2002,2010)$ står bag konceptet relationel koordinering, som har fået meget stor udbredelse indenfor sygehussektoren. Hun har fået stor bevågenhed i forbindelse med sin forskning i amerikanske flyselskaber og hospitalssektoren, hvor hun fokuserer på, hvad der gør dem effektive. Gittell refererer både direkte og indirekte til Bourdieu (Gittell 2002: 301) i sin forståelse af social kapital, som hun videreudvikler til begrebet organisatorisk kapital. Det defineres som: "en form for social kapital som eksisterer i og kan udvikles i organisationerne som en distinkt 
Tema: Professioner og tværprofessionalitet

organisatorisk kapacitet og en kilde til konkurrencefordele" (Gittell, Seidner \& Wimbush 2010: 491).

Gittell foretager en transformation af Bourdieus begreb om social kapital, idet hun frit fortolker og omsætter begrebet til et organisatorisk værktøj, som lover konkurrencemæssige fordele. Gittell understreger desuden, at "organisatorisk social kapital har vist sig at forbedre (virksomhedens) performance ved at gøre de ansatte i stand til at få adgang til de ressourcer, som ligger i et givet netværk ved at facilitere overførsel og deling af viden" (Gittell 2010: 491). Med transformationen fra social kapital til organisatorisk social kapital ændres fokus fra et analytisk begreb til at forstå social reproduktion i samfundet til at komme med handlingsanvisninger til at øge produktiviteten og kvaliteten af virksomhedens resultater. Hvor Bourdieu tænker social kapital i sammenhæng med, at et individ eller gruppe kan høste erfaringer af sine individuelle relationer i givne sociale felter, bliver relationen hos Gittell en organisation, hvor alle angiveligt har et fælles mål i lighed med kerneopgaven i virksomhedens sociale kapital.

I Gittells studier af hospitalssektoren i USA viser hun, hvordan der er klare effektivitetsfordele ved at arbejde med relationel koordinering. Hun viser tydelige sammenhænge mellem behandlingskvalitet, indlæggelsestid og kvaliteten af relationel koordinering, som hun definerer som "en gensidig forstærket interaktionsproces mellem kommunikation og relationer gennemført med det formål at integrere opgaver" (Gittell 2002: 301). Gittell taler til en hverdagsforståelse af, at det er vigtigt at koordinere sine arbejdsopgaver med hinanden. Heri ligger en antagelse om, at der i enhver arbejdspraksis gives mulighed for en koordineret fælles indsats. Det gælder også i situationer, hvor opgaverne er indbyrdes afhængige, men præget af usikkerhed og tidspres. For Gittell er det en vigtig pointe, at der opnås højere effektivitet, når alle i organisationen har fælles mål, deler viden og har gensidig respekt for hinanden. I sin seneste publikation understreger Gittell, at relationel koordinering kan bidrage til at forbedre de hospitalsansattes psykosociale velvære i en situation med økonomiske stramninger og besparelser, hvor de ellers ville føle sig pressede. Hun argumenterer for, at når kolleger deler deres oplevelse af stress med hinanden, reduceres de negative virkninger (Gittell 2016: 1702).

Med begreber som præstation, resiliens, effektivitet og kvalitet, som ikke nærmere defineres, argumenterer Gittell for, at der er en klar sammenhæng mellem graden af koordinering og samarbejde blandt de ansatte og antallet af fejl, der begås under løsningen af opgaverne. Samtidig forbedres de ansattes psykosociale velvære eller trivsel. Det er derfor ikke mærkeligt, at relationel koordinering vinder stor udbredelse indenfor en sektor, som netop er trængt af økonomiske stramninger, fejl, kvalitetskrav og stort arbejdspres. Relationel koordinering præsenteres således som en mulig opskrift på at løse vanskelige og komplekse problemer, uden at der skal tilføjes ekstra ressourcer.

\section{Virksomhedens sociale kapital og relationel koordinering $i$ en dansk hospitalskontekst \\ Det empiriske materiale, som artiklen}

diskuterer ud fra, stammer fra et større forskningsprojekt, der undersøgte, hvordan nye organiserings- og styringsformer indvirker på sygeplejerskers og lægers arbejde. Det blev udført af en af forfatterne bag artiklen (Ernst 2016). Det bestod af et 13 måneder langt etnografisk feltarbejde på en hospitalsafdeling med observationer af sygeplejerskers og lægers arbejde, mødeobservationer og interview. Der blev taget feltnoter af observationerne, og alle interviews blev transskriberet. Derudover bestod materialet af interne dokumenter fra afdelingen, herunder udskrifter af resultaterne fra to medarbejderundersøgelser.

Af dette materiale fremgik det, at social kapital var et af de nye ledelsesværktøjer, som havde indvirkning på de ansattes dagligdag. Derudover blev nævnt systemer til standardisering af arbejdet, akkreditering og monitorering. Med det formål at forstå, hvorfor det blev besluttet at indføre social kapital, samt hvordan det blev introduceret i organisationen og siden anvendt i praksis, besluttede forskeren at følge værktøjets vej fra hospitalsafdelingen tilbage til hospitalsledelsen og videre tilbage til regionen, hvor beslutningerne omkring indførelsen af social kapital på alle regionens hospitaler var blevet truffet. Analysen af social kapital bygger på det samlede empiriske materiale, som blev suppleret med interviews med tre informanter, som hver især havde spillet en central rolle i forbindelse med indførelsen af social kapital i den lokale setting. Desuden indgik et medarbejdermøde, hvor resultaterne af en trivselsmåling blev diskuteret. De tre informanter var ansat på henholdsvis regionalt niveau, hospitalsniveau og afdelingsniveau. Spørgsmålene havde til formål at afdække interviewpersonernes 


\section{I virksomhedens sociale kapital er det ikke den skandinaviske forståelse af tillid, som indgår.}

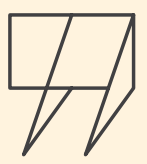

involvering i arbejdet med social kapital ud fra den pågældendes jobmæssige position.

\section{Social kapital som ledelsesmæssigt redskab \\ Beslutningen om, at regionen vil anvende konceptet om social kapital, opstår i forbindelse med en konference, hvor en af forfatterne bag Hvidbogen holder et foredrag om social kapital. Den tilgang, som regionen efterfølgende anvender, er inspireret af såvel Hvidbogen som Git- tells begreb om relationel koordinering. Hospitalsdirektionen tager initiativet og er i udgangspunktet primært interes- seret i mulighederne for at måle den sociale kapital og sammenligne afdelin- ger med hinanden.}

På regionsniveau bliver social kapital efterfølgende introduceret som det, alle afdelinger skal måles på. Samtidig er det en vigtig del af beslutningen, at det er de ansatte selv, der skal definere, hvad de forstår ved social kapital ud fra en beslutning om, at der ikke skal være topdown styring i forhold til begrebernes betydning. Rationalet bag dette er, at der kan være meget store forskelle på, hvad der kan lægges i ordene, og at forståelserne skal fastsættes blandt de ansatte ud fra et demokratiseringshensyn.

Der måles på tillid, retfærdighed og samarbejdsevne, men det er op til hver enkelt selv at finde ud af, hvad de vil lægge i disse tre ord, for som regionsrepræsentanten siger: "Vi kan jo ikke styre, hvad folk tænker, når de læser spørgsmålene. Man kan bruge det til en efterfølgende dialog med medarbejderne, hvor man spørger, hvad de har forstået ved tingene". Efterfølgende konkluderer regionsrepræsentanten, at det ikke er helt uproblematisk at gøre det på denne måde, når der er så store forskelle på, hvad medarbejderne forstår ved ordene, og det derfor er vanskeligt at skabe enighed om, hvad der menes.

På hospitalsniveau bliver regionens udspil om social kapital godt modtaget, især arbejdsmiljøorganisationen er meget positiv og forventningsfuld og den person, som bliver ansvarlig for at implementere social kapital på sygehuset, ser det som en god mulighed til at forbedre arbejdsmiljøet. Den ansvarlige for implementeringen betragter social kapital som en ny måde at åbne dørene ind til ledelsen: "Det er ikke bare topdown". Derudover udtrykker den ansvarlige, at det "giver mulighed for at arbejde med arbejdsmiljø på en ny måde, så der ikke kun er fokus på fejl og mangler, men også på et udviklingsperspektiv".

Efter at have arbejdet med social kapital i flere år, er det tydeligt, at det ikke har levet op til forventningerne, for som den ansvarlige formulerer det: " Der var mange i det her land, som pludselig greb alt omkring social kapital, og måske lidt for ureflekteret. Det blev det nye sort. Nu arbejder alle sygehuse med det, og som sådan er det jo ikke noget særligt".

På afdelingsniveau er der ligeledes store forventninger til, hvad det at arbejde med social kapital kan betyde fremover, især i forhold til en dialog med ledelsen omkring væsentlige forhold vedrørende den daglige arbejdspraksis. Medarbejderne ser derfor social kapital som en god anledning til at tage væsentlige forhold op med ledelsen. Det gælder 


\section{Social kapital kan vende sig til sin egen modsætning, hvis ikke medarbejderne oplever at blive hørt og taget alvorligt.}

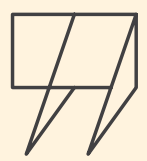

problemer med manglende ressourcer i afdelingen, bemandingsplaner der ikke fungerer, nye arbejdsdelinger personalegrupperne imellem i forbindelse med nye teknologier og behandlingsformer og problemer med at få dækket nattevagter. På et møde, hvor den årlige medarbejdertilfredshedsundersøgelse bliver evaluereret, kommenterer nogle af sygeplejerskerne, at der er en ulige fordeling af nattevagter på afdelingen. I stedet for at vende blikket mod eventuelle begrænsninger i ressourcerne eller andre strukturelle forhold bliver blikket rettet mod medarbejderne, idet den lokale ledelse påpeger, at problemet med fordelingen må bunde i for lav social kapital blandt sygeplejerskerne, når de ikke kan løse det selv: "Husk at dette handler om jeres sociale kapital. Kan I finde ud af det indbyrdes eller må vi ledere tage over og forvalte ud fra nogle regler?".

For lederen af afdelingen er det et problem, når afdelingen ikke scorer højt på social kapital. På de årlige dialogmøder med hospitalsdirektionen bliver det bemærket, hvis en afdeling kommer ud med et resultat, som ligger under gennemsnittet, og afdelingen skal kunne forklare, hvad der er årsagen til dette. Lederen fortæller, at direktionen på det årlige møde med afdelingsledelsen gav udtryk for, at afdelingens sociale kapital var under det forventede, og at forventningerne til afdelingen ellers var høje på grund af afdelingens mange spændende opgaver og det dygtige personale. Lederen fortæller, at de har haft et "vanvittigt hårdt år" og "meget pres på", og at de lige nu har en personaleomsætning, som er meget høj. Dette afspejler sig i måleresultaterne og viser samtidig de udfordringer, det skaber at måle og sammenligne på nogle faktorer, der ikke afspejler de ændrede rammer for arbejdet i form at travlhed, høj personaleomsætning $\mathrm{mm}$.

På regionsniveau ønskede ledelsen et værktøj til at måle på social kapital, hvad angik tillid, retfærdighed og samarbejde, for at få et overblik og kunne sammenligne de enkelte sygehuse og afdelinger med hinanden.
På hospitalsniveau var målet at rette fokus på samarbejdskommunikationen medarbejderne imellem for på den måde at "skabe en kultur med respekt for de faglige forskelligheder i arbejdet". På afdelingsniveau blev resultatet, at social kapital blev brugt til at fokusere på, at det var medarbejderne, der skulle ændre deres indstilling til arbejdet og dermed fjerne opmærksomheden fra at ændre de vilkår, som arbejdet foregik under. De positive forventninger til forbedring af arbejdsmiljøet og dialogen med ledelsen blev derfor ikke indfriet. Målingerne af social kapital blev således den primære aktivitet.

\section{Diskussion}

Vi har med denne artikel haft som mål at illustrere nogle af de vanskeligheder, der skabes, når sociologiske koncepter vandrer og skifter betydning i omdannelsen til ledelseskoncepter, sådan som vi har set det med begrebet om social kapital. Når begreber som signalerer samarbejde, tillid og ligeværdighed om opgaven bringes ind i en organisatorisk kontekst, underlægges de ledelsens fortolkning, 
Samarbejde via social kapital og relationel koordinering - hvem trækker det længste strå?

hvilket forvirrer medarbejderne, der ofte har en anden forståelse af begreberne. På den måde kan indførelsen af social kapital som ledelseskoncept vende sig til sin egen modsætning, når medarbejderne ikke gør, hvad ledelsen forventer af dem, som eksemplet med fordelingen af nattevagterne viste.

\section{Begreber der ikke defineres kan ikke kritiseres}

I hospitalscasen fremhæves det som vigtigt, at der ikke er nogen fast definition på, hvad der menes med social kapital. Det fremstilles endog som et ønske fra medarbejderne, at de selv skal være med til at definere, hvad de lægger i begreberne. Men som casen illustrerer, har medarbejderne mange meninger herom, og de når tilsyneladende ikke til enighed. Alligevel måles der årligt på tillid, retfærdighed og samarbejdsevne, og afdelingerne bliver af hospitalsdirektionen stillet til regnskab for måleresultatet. Det bevidste fravær af en fælles definition af begrebet social kapital skaber forvirring og er ikke en styrke, da det kan være med til at gøre det meget vanskeligt at insistere på de udfordringer, der ligger $\mathrm{i}$ at løse de daglige arbejdsopgaver. Som Rasmus Willig (2014) spidsformulerer det, kan det ikke at definere og indholdsbestemme ord og begreber gøre det langt mere vanskeligt at forholde sig kritisk, da det bliver uklart, hvad man skal rette kritikken mod.

Maja Sasser (2016) har gennemført et studie af, hvordan medarbejderne samarbejder omkring kerneopgaven ved hjælp af social kapital. Hun konkluderer, at når medarbejderne skal definere, hvad de forstår ved kerneopgaven, er det ikke så vanskeligt at komme til enighed herom på det overordnede plan.
Enigheden ophører dog, når det kommer til den daglige arbejdspraksis, og det er ikke ualmindeligt, at der opstår konflikter omkring, hvad kerneopgaven i praksis betyder. Hermed leverer hun et bidrag til kritikken af den måde både social kapital og relationel koordinering anvendes på i forhold til at fokusere på medarbejderne og deres evne og vilje til bedre kommunikation og samarbejde i stedet for at fokusere på, hvor vigtigt det er at skabe respekt og forståelse for kompleksiteten i et arbejde, som foregår under mange former for pres.

Samarbejde og tillid hænger sammen, og tillid er ifølge Løgstrup noget et menneske har og ikke noget, den enkelte kan beslutte sig for at have og derfor ikke noget, der kan dikteres. Er der ikke tillid, opstår mistillid, hvilket let opstår, hvis medarbejderne ikke oplever, at de bliver taget alvorligt og lyttet til. Social kapital kan derfor vende sig til sin egen modsætning, hvis ikke medarbejderne oplever at blive hørt og taget alvorligt. Det har derfor stor betydning, hvilken forståelse af tillid, der er på arbejdspladsen. Er det Løgstrups forståelse eller den tyske og angelsaksiske udlægning, hvor tillid er noget, den enkelte kan beslutte sig for og derfor noget, der har med medarbejdernes villighed at gøre?

\section{Hvem definerer det gode samarbejde?}

At indføre social kapital eller relationel koordinering i hospitalssektoren skaber derfor ikke af sig selv et godt samarbejde og en samarbejdskultur i en organisation, der er udfordret af stort arbejdspres, nedskæringer, mangel på personale $\mathrm{mm}$. Et spørgsmål i den forbindelse er, hvad et godt samarbejde indebærer, og hvem der definerer det. Der er ifølge LehnChristensen (2016) en kamp om, hvordan samarbejde indenfor sundhedssektoren skal foregå. Hun udfolder fire aktuelle diskurser, hvor relationel koordinering er en af de fire. I denne diskurs skal eventuelle interessekonflikter løses gennem et stærkere fokus på organisationens opgaver og udfordringer, hvor kollegers gensidige respekt for hinandens fagligheder primært ses som et middel til at nå målet (Lehn-Christensen 2016: 16-17). Dette står ifølge Lehn-Christensen i modsætning til det, hun betegner som en demokratiseret professionspraksis, hvor der er fokus på nye måder at samarbejde på gennem en ændret indstilling til det at være sundhedsprofessionel i forhold til andre professioner og til patienterne.

\section{Samarbejde via social kapital og relationel koordinering - hvem trækker det længste strå?}

Social kapitals afsæt i forskning er med til at legitimere social kapital og gør det svært for medarbejderne at gennemskue, hvad det indebærer, når det indføres som et ledelseskoncept. At konceptet trækker på forskningsbaseret viden understøttes af, at det til en vis grad er forskere, der har transformeret begreberne til ledelseskoncepter og værktøjer. De fungerer samtidig som konsulenter $\mathrm{i}$ virksomheder, udbyder kurser og skriver let tilgængelige pjecer med eksempler på værktøjer, som kan downloades fra internettet.

Så selvom koncepterne social kapital og relationel koordinering af deres udviklere præsenteres som en måde at skabe en bedre samarbejdskultur på eller at vende en konfliktkultur til en samarbejdskultur (Hasle \& Møller 2005), kan dette vise sig vanskeligt i praksis. Der er ingen opskrift eller 'quick fix' at trække på, som Hagedorn-Rasmussen (2014) påpeger 


\section{I stedet for at løse de daglige problemer tales der om, hvorvidt den sociale kapital er lav eller høj, hvilket fjerner fokus fra det daglige arbejdes udfordringer.}

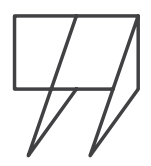

i sin analyse af en række projekter og indsatser, der omhandler social kapital. Strukturelt betingede udfordringer og professioners forskellige faglighed og tilgang til opgavevaretagelsen ændres ikke ved, at ledelsen beslutter, at 'vi skal blive enige om opgaven, have tillid til hinanden, opleve det som retfærdigt og indgå samarbejde omkring det'. I stedet er der brug for at opbygge nye praksisser, som muliggør tillid, retfærdighed og samarbejde. De forskellige professioner har forskellige opgaver at varetage, som er centrale for netop deres profession, og som de er ansat til at udføre. Det er selvfølgelig vigtigt at kommunikere med hinanden på kryds og tværs om løsning af arbejdsopgaverne og få større forståelse for hinandens arbejde. Men bedre kommunikation og samarbejde løser ikke i sig selv de massive udfordringer, som hospitalssektoren står med i form af besparelser på ressourcer, manglende tid og stigende krav fra borgerne om større indsigt, mere kommunikation og optimal behandling.

Ved at indføre koncepter som virksomhedens sociale kapital og/eller relationel koordinering som en måde at gøre medarbejderne og deres samarbejdsevne ansvarlige for hospitalets produktivitet, effektivitet og kvalitet kan der ske det modsatte af hensigten. Koncepterne er først og fremmest rettet mod medarbejdernes evne og villighed til samarbejde og i langt mindre grad mod at forbedre de økonomiske og strukturelle vilkår omkring arbejdet.

I casen måler en given ledelse på et hospital på social kapital og stiller afdelingerne til ansvar for resultaterne, især hvis resultatet ligger lavt. Det kan der være mange grunde til, ikke desto mindre rettes fokus på medarbejdernes manglende sociale kapital og ikke på vilkårene for arbejdet. I stedet for at løse de daglige problemer tales der om, hvorvidt den sociale kapital er lav eller høj, hvilket fjerner fokus fra det daglige arbejdes udfordringer.

Kommunikation og samarbejde tager tid og plads, så social kapital og relationel koordinering risikerer blot at blive endnu en opgave oveni alt det andet, som lægges over på medarbejderne, som i forvejen er pressede. For medarbejderne kan det betyde, at de vender det indad og oplever, at det er deres egen skyld ikke at kunne løse det uløselige, som Tynells studie (Tynell 2002) og mange andre studier har vist (Buch m.fl. 2009). Stress og udbrændthed kan blive resultatet, hvis der skabes en 'det er min egen skyld'-kultur, en afmægtighedskultur eller måske en konfliktkultur. I stedet for at opbygge tillid og samarbejdsevne kan der ske en svækkelse, stik imod hensigten, hvilket også Hagedorn-Rasmussen (2014) gør opmærksom på. På den måde er koncepterne med til at legitimere en ledelsespraksis og nogle magtforhold, der ligger langt fra de teoretiske begreber, som koncepterne hentede deres inspiration og legitimitet fra. Samtidig har koncepterne yderst vanskeligt ved at leve op til det, de lover, nemlig at skabe overensstemmelse mellem produktivitet, kvalitet og et godt psykisk arbejdsmiljø.

Så hvem trækker det længste strå? Det er der måske ingen, der gør, så længe hospitalssektoren skal håndtere så mange komplekse og modstridende krav på én og samme gang. 
Samarbejde via social kapital og relationel koordinering - hvem trækker det længste strå?

\section{REFERENCES}

Albertsen K., Wiegman K-M \& Limborg, H.J. (2014). Virksomhedens sociale kapital og relationelle koordinering - hvordan hænger det sammen? Tidskrift for Arbejdsliv 16: 32 - 49. http://www.nyt-om-arbejdsliv.dk/images/pdf/2014/nr4/ tfa4_2014_032_049.pdf

Bourdieu, P. (1986). The forms of capital. In J. Richardson (Ed.) Handbook of Theory and Research for the Sociology of Education (New York, Greenwood), pp. 241-258.

Bruhn, P., \& Hagedorn-Rasmussen, P. (2013). At arbejde med social kapital. Branche Arbejsmiljørådene Social \& Sundhed, Undervisning \& Forskning samt Finans / Offentlig Kontor \& Administration.

Buch, A., Andersen, V., \& Sørensen, O.H. (2009). Videnarbejde og stress. Jurist- og Økonomforbundets Forlag.

Edwards K. \& Lundstrøm S.L. (2014). Relationel koordinering kan ændringer i samarbejde måles? Tidsskrift for Arbejdsliv 4: 50 - 68. http://www.nyt-om-arbejdsliv.dk/images/pdf/2014/nr4/ tfa4_2014_050_068.pdf

Ernst, J. (2016). Evidence-based nursing in the IED: From caring to curing? Nordic Journal of Working Life Studies 6 (S 1): 47-66.

Fink, H. (2016). Om tillid, mistillid og professionsetik. Tidsskrift for Professionsstudier 22, 6-14.

Gittell, J.H. (2002). Relationships between Service Providers and Their Impact on Customers. Journal of Service Research 4(4), 299-311.

Gittell, J.H., Seidner, R., \& Wimbush, J. (2010). A relational model of how high-performance work systems work. Organization science, 21(2), 490-506.

Gittell, J.H. (2016). Rethinking Autonomy: Relationships as a Source of Resilience in a Changing Healthcare System. Health Services Research, 51(5), 1701-1705.

Lehn-Christiansen, S. (2016): Kampen om tværsamarbejdet. Tidsskrift for Arbejdsliv. 18(4), 8-24.

Limborg, H.J., Albertsen, K., Jensen, M.J. \& Jensen \& Pedersen, F. (2012). Engagement eller Mistillid - Håndtering af dokumentationskrav i folkeskolen. TeamArbejdsliv. Valby

Lundstrøm, S.L., Edwards, K., Knudsen, T.B. \& Larsen P.V. m.fl. (2014). Relational coordination and organisational social capital association with characteristics of general practice. International Journal of Family Medicine 2014: 618435.

Løgstrup. K. E. (1956/2010): Den etiske fordring. Løgstrup biblioteket. Klim.

Hagedorn-Rasmussen, P. (2014). Social kapitals renæssance i en arbejdslivskontekst - jagten på guldkorn og diamanter mellem meningsskabelse og forførelse? Tidskrift for Arbejdsliv. 16(4), 11-31. http://www.nyt-om-arbejdsliv.dk/images/pdf/2014/nr4/ tfa4_2014_011_031.pdf

Hasle, P. \& Møller, N. (2005). Fra en konfliktkultur til udvikling i fællesskab. Social kapital i danske slagterier. Tidsskrift for Arbejdsliv nr. 7(3), 71-86. http://www.nyt-om-arbejdsliv.dk/ images/pdf/2005/nr3/ta05-3-71.pdf

Hegedahl, P. \& Rosenmeier, S.L. (red.) (2007). Social kapital som teori og praksis. Samfundslitteratur.

Kristensen, T.S., Limborg H.J., Albertsen, K. \& Pedersen, F. (2013). Jobbet eller arbejdspladsen - hvad betyder mest? En analyse af social kapital i folkeskoler. Tidskrift for Arbejdsliv 3: 62 - 77. http://www.nyt-om-arbejdsliv.dk/images/pdf/2013/nr3/ tfa3_2013_062_077.pdf

Olesen, K.G., Thoft, E., Hasle, P., \& Kristensen, T. (2008). Virksomhedens sociale kapital. Hvidbog. Arbejdsmiljørådet. Det Nationale Forskningscenter for Arbejdsmiljø.

Portes, A. (1998). Social Capital. Its Origins and Applications in Modern Sociology. Annual Review of Sociology 24: 1-24.

Putnam, R.D. (1995). Bowling alone: America's declining social capital. Journal of democracy, 6(1), 65-78.

Sasser, M. (2016). Kerneopgaven og det meningsfulde arbejde - et studie af meningsskabelse i det pœdagogiske arbejde. Ph.d-afhandling. Institut for Arbejdsliv, Roskilde Universitet.

Tynell, J. (2002). "Det er min egen skyld" - om nyliberale styringsrationaler indenfor Human Resuorce Management. Tidsskrift for arbejdsliv nr. 4(2), 7-24. http://www.nyt-om-arbejdsliv. dk/images/pdf/2002/nr2/ta02-2-7.pdf

Vinge, S. (2004). Kontinuitetens paradoks. I Vikkelsø, S. \&Vinge, S. (eds.): Hverdagens arbejde og organisering i sundhedsvcesenet. Handelshøjskolens Forlag. København. 210-227.

Willig, R. (2013). Kritikkens u-vending. Hans Reizels Forlag. 